\title{
CHILLED AND FROZEN MARGINS - EVIDENCE OF THERMAL CONTRAST IN MAFIC DYKES AND THEIR SIGNIFICANCE FOR MAGMATIC CONSOLIDATION
}

\author{
L.C.Corrêa-Gomes' \\ M.N.Souza ${ }^{2}$ \\ D.R.Correia ${ }^{2}$
}

\section{INTRODUCTION}

When a magma rising through the lithosphere contacts "cold" wallrocks a thermal contrast occurs at the interface, which deminishes slowly inwards from the contact. Ideally, a sequence of zones parallel to the contact would be created having the following fabrics from the margin to the centre of the conduit: a) Holohyaline (>90\% glass), b) Hyalocrystalline ( $90 \%$ to $10 \%$ glass), and c) Holocrystalline (<10\% glass). Grain size in the central zones depends obviously on the time necessary for total magma consolidation.

Although rheological expectation would seem to indicate that the larger the thermal contrast and magma volume in the system, the thicker the chilled margins should be (JAEGER, 1967), observations on mafic dykes from southern France (FABRE et al., 1989) have proved the contrary.

Continuous magma movement within the conduit, until total immobilization, is responsible for margin reheating and reduction by devitrification, "softening" and erosion due to magmatic flux.

Thus, the observation of mafic dyke contacts can provide important information on the thermal evolution of magmatic cooling, especially when dykes of different thicknesses from the same area are compared. Along the coast of the city of Salvador, Bahia, several well-preserved dykes

\footnotetext{
'Universidade Federal da Bahia, Rua Caetano Moura, 123, 40210 Salvador, BA, Brazil - Universidade Católica, 40210 Salvador, BA, Brazil.

${ }^{2}$ Universidade Federal da Bahia, Rua Caetano Moura, 123, 40210 Salvador, BA, Brazil.
} 
unaffected by metamorphism crop out with the above characteristics and are, therefore, suitable for such analysis.

\section{LOCATION AND METHODOLOGY}

The mafic dyke system under study out in the Rio Vermelho district of Salvador (Fig. 1 ) is represented by a dyke having a complex bifurcate geometry (Fig. 2) in which the principal branch is $26 \mathrm{~m}$ thick, and the lateral ramification reaches $1.65 \mathrm{~m}$ in thickness. Small mafic veins (8 cm thick) complete the local scenario.

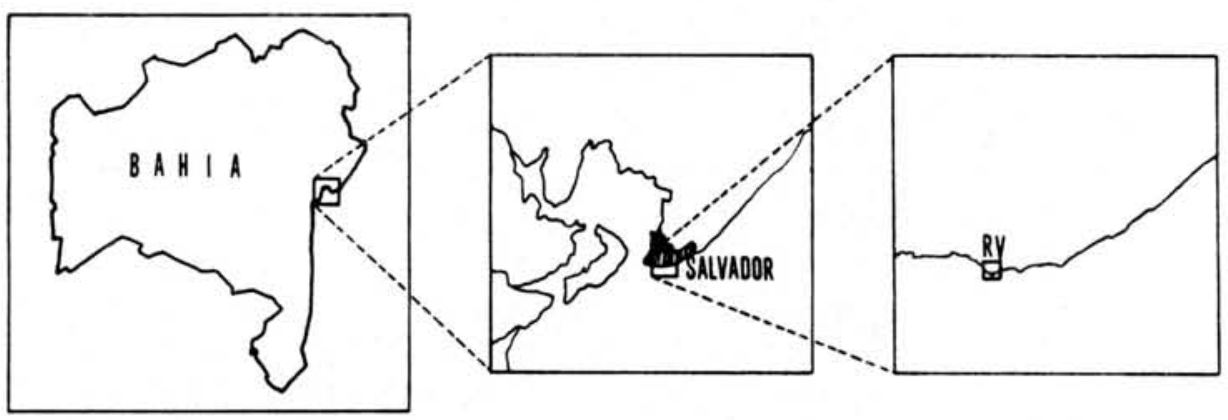

Figure 1 - Location map. RV = Rio Vermelho district.
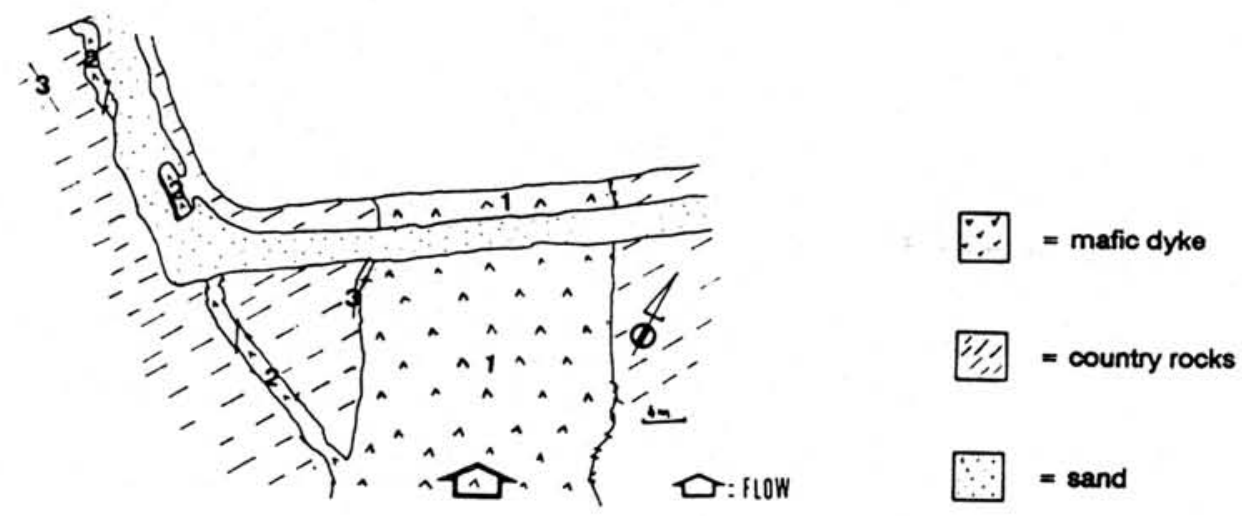

Figure 2 - Schematic aspect of mafic dyke from beach at Hotel Meridien. 1)Principal body, 2) lateral branch, 3) veinlets. 
The basement consists of Transamazonian (2.0 Ga; CORDANI, 1973) migmatized granulites that exhibit banded to locally massive structures. These rocks are thought to belong to the Atlantic granulite belt (INDA \& BARBOSA, 1978).

The dykes are composed of labradorite, pigeonite and/or augite, opaques, and rare olvine (TANNER de OLVEIRA \& CONCEIÇÃO, 1982). In outcrop dykes exhibit fine-grained margins of variable thickness, sometimes irregular. These quenched margins parallel the country rock contact and are distinguished by their fabric variation, colour, luster, roughness, and fracture (conchoidal, planar).

\section{DEVELOPMENT OF CHILLED AND FROZEN DYKE CONTACTS}

Experimental work on solidification of basaltic magmas has indicated cooling rates on the order of up to $1000^{\circ} \mathrm{C} / \mathrm{h}$ for glass formation (LOEFGREN et al., 1974; SCHIFFMANN \& LOEFGREN, 1982). Spherulites and microlites form at cooling rates of about $800^{\circ} \mathrm{C} / \mathrm{h}$ (FABRE et al., 1989). These are the most adequate thermal conditions for formation of chilled margins.

However, if reaction phenomena related to metamorphism or internal exothermic reactions during magmatic solidification take place, the temperature may rise and, eventually lead to partial recrystallization (BEAL \& RITTLER, 1976), and/or "softening" and refusion (LEBEAU \& GIROD, 1987). Thus, when dykes are not affected by "metamorphism", the longer the duration of internal magmatic flux, the thinner will be the chilled margins.

In Figure 3 the percentage of glass is plotted for dykes of differing thicknesses

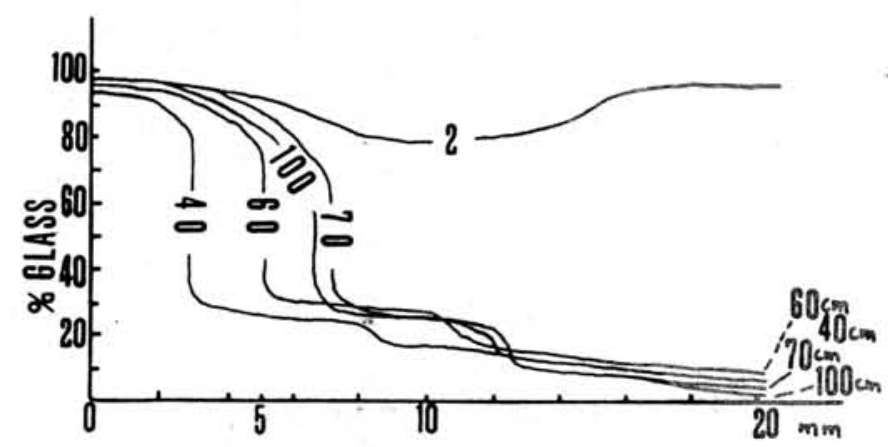

Figure 3 - Graph of glass percentage in dykes of different thicknesses $(100,70,60,40$ and $2 \mathrm{~cm})$ versus distance to borders (mm) (FABRE et al., 1989). 
against distance from the country rock contact (FABRE et al., 1989). Clearly defined are plateaus near the values of $90 \%, 30 \%$ and, $10 \%$ glass. These percentages may be related to those utilized to characterize holohyaline, hyalocrystalline and holocrystalline fabrics. The visual distinction of a glassy border is fairly easy, but recognition of the other two glass levels (i.e. $30 \%$ and $10 \%$ ), is not, and therefore these have been considered here as a single zone. Nevertheless, these levels have received specific denominations, because they do reflect different cooling rates here indicated as frozen margins (FM) and, more internally, chilled margins (CM) distinct from the outer glassy border.

The measurements summarized in Table 1 show some remarkable differences:

- In the principal dyke (26 $\mathrm{m}$ thick), the absence of FMs is evident, but CMs are thick, reaching $150 \mathrm{~mm}$; the latter contain rare phenocrystals (xenocrystals) of plagioclase, $2.0 \mathrm{~mm}$ long, which are also found up to about $1 \mathrm{~m}$ from the border. These crystals have a small tabular shape, common to feldspars formed by reaction between crystals and liquid induced by intramagmatic exothermic reactions that ultimately could result in the destruction of FMs. As the temperature decreases, CMs could grow without impediment. Inwardly, crystal size evolves to medium to coarse phaneritic texture.

- In the lateral branch (1.50 $\mathrm{m}$ to $1.65 \mathrm{~m}$ thick), the narrow parts show thicker CMs and FMs. Here also the typical irregular FM shapes are important as they evidence partial destruction by reheating and erosion in a continual-flow regime.

- In the 8-cm-thick veins, the CM and FM thicknesses are proportionally thicker than in the dyke and lateral branch (see Table 1).

In addition to these features, other evidence regarding the differentiated latent calorific potential of the dyke can be derived from the shapes of contacts: linear and well defined in the thinner bodies, to irregular and confused in the main body, the latter representing the largest thermal echange with the country rocks.

A schematic summary of the principal aspects referred to above is shown in Figure 4.

\section{CONCLUSIONS}

Some important conclusions can be drawn from the FMs and CMs in the studied examples:

1) The choice and identification of margins as being of the $F M$ and $C M$ types are 
Table 1 - Thickness of chilled (CM) and frozen (FM) margins in the dykes.

\begin{tabular}{|c|c|}
\hline $\begin{array}{l}\text { DYKE } \\
(\mathrm{cm})\end{array}$ & $\begin{array}{c}\text { THICKNESS } \\
\text { CM } \\
(\mathrm{mm})\end{array}$ \\
\hline
\end{tabular}

PRINCIPAL

BODY*

$2600 \quad 150$

$\begin{array}{lrrr} & 165 & 20 & 5 \\ \text { LATERAL } & 260 & 42 & 6 \\ \text { BRANCH } & 150 & 60 & 11 \\ & 145 & 45 & 10 \\ & 145 & 33 & 7\end{array}$

VEINLETS** $\quad 4 \quad 5 \quad 15$

*average of 8 measurements; **average of 6 measurements.

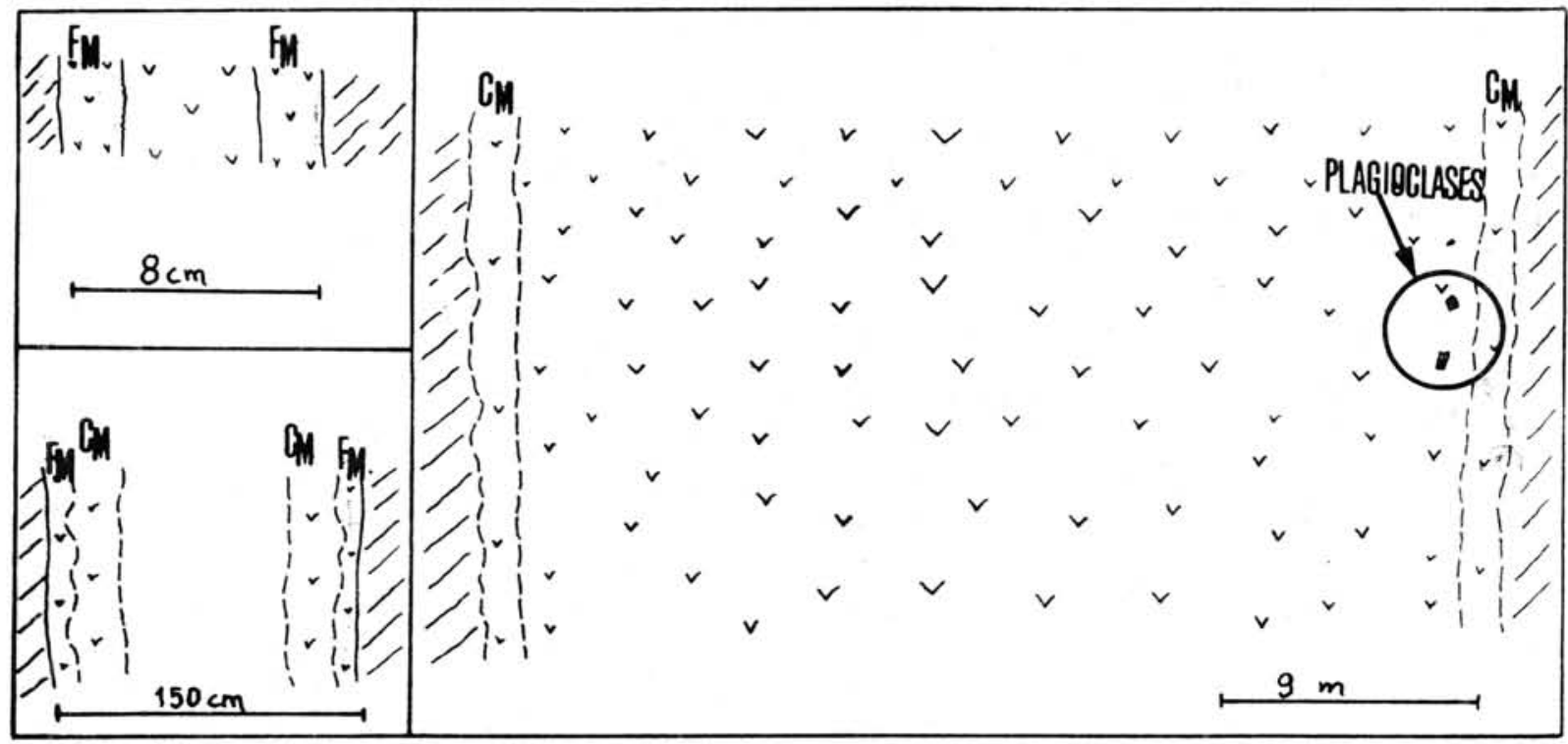

Figure 4 - Summary of principal aspects associated with mafic dykes. $C M=$ chilled margins, $F M=$ frozen margins. Plagioclase phenocrysts are indicated in the circle. 
necessary for a better analysis of the thermal behaviour of dykes. The option of chilled margins alone is not enough to show complete thermal evolution.

2) The absence of a $F M$ in the principal dyke $(26 \mathrm{~m})$, combined with the thickness of its CMs, indicates greater resistence of CMs to thermal transformation than FMs.

3) Phenocrysts with rounded shape, irregular contacts, the absence of $F M$, and the lack of evidence of metamorphism in the dykes allow the conclusion that the source of heat was internal.

4) The longer the cooling time of a magma the greater the destruction of the FM and the greater the possibility of $C M$ formation.

5) The formation/destruction stages of FMs can be observed by comparing their regular form in the veins with their irregular shape in the lateral branch and their absence in the principal body.

\section{REFERENCES}

BEAL, G.H. \& RITTLER, H.L. (1976) Basalt glass ceramics. American Ceramic Society Bulletin, 55:579-583.

CORDANI, U.G. (1973) Evoluç o geológica precambriana da faixa costeira do Brasil entre Salvador e Vitória. S o Paulo, 98p. (Tese de Livre Docência- Instituto de Geociências/USP).

FABRE, P.; KAST, Y.; GIROD, M. (1989) Estimation of flow duration of basaltic magma in fissures. Journal Volcanology and Geothermal Research, 37:167-186.

INDA, H.A. \& BARBOSA, J.F. (1978) Texto explicativo para o mapa geológico do Estado da Bahia. Salvador, SME/CPM. Escala 1:1.000.000.

JAEGER, J.C. (1967) Cooling and solidification of igneous rocks. In: HESS, H.H. \& POLDERVAART, A. (1967) Basalts: the poldervant treatise on rocks of basaltic composition. New York, Interscience Publishers. V.2, p.503-536.

LEBEAU, M.J. \& GIROD, M. (1987) Incorporation of simulated nuclear ashes in basalts: an 
experimental investigation. American Ceramic Society Bulletin, 66(11):1640-1646.

LOFGREN, G.E.; DONALDSON, C.H.; WILUAMS, R.J.; MULUNS, O.J.; USSELMAN, T.M. (1974) An experimentally reproduced textures and mineral chemistry of Apollo 15 quartz normative basalts. Proc. 5th. Lunar Conf.Geochem.Cosmochem. Acta, 1:549-567.

SCHIFFMAN, P. \& LOFGREN, G.E. (1982) Dynamic crystallization studies on the Grande Ronde pillow basalts, Central Washington. Journal of Geology, 90:49-78.

TANNER DE OLVEIRA, M.A.F. \& CONCEIÇÃO, H. (1982) Metamorfismo de alto grau da faixa costeira de Salvador, BA. In: CONGRESSO BRASILEIRO DE GEOLOGIA, 32., Salvador, 1982. Anais. Salvador. SBG. V.2, p.603-613. 